\title{
DOES THE RIGHT TO USE DIGITAL CONTENT AFFECT OUR DIGITAL INHERITANCE?
}

\author{
Romana Matanovac Vučković, PhD, Associate Professor \\ University of Zagreb, Faculty of Law \\ Trg Republike Hrvatske 14, Zagreb, Croatia \\ romana.matanovac.vuckovic@pravo.hr
}

\author{
Ivana Kanceljak, PhD, Assistant Professor \\ University of Zagreb, Faculty of Law \\ Trg Republike Hrvatske 14, Zagreb, Croatia \\ ivana.kanceljak@pravo.hr
}

\begin{abstract}
Rights in the digital world affect our property in a special way. This paper aims to explain how users right in a digital world reflect on user's estate of inheritance. Firstly, it is explained what digital content is and what digital services are. After that, digital content and services are discussed from the user's point of view having in mind rights that users have in a digital world. Although those rights contain a right to use data or services they are created and regulated through different provisions (copyright, intellectual property, ownership or licences).

Under the principle of universal succession, everything that belonged to decedent can belong to his or her heirs unless it is explicitly regulated otherwise or rights are strictly personal. Despite this principle there are some rights in the digital world that cannot belong to the heirs. Also, existence of a digital inheritance might cause some practical problems.
\end{abstract}

Keywords: digital content, digital data, right to use, inheritance, copyright, licences

\section{INTRODUCTION}

Digitalisation and technologies have changed our everyday lives. A variety of digital contents and digital services, free or for consideration, have already changed our property. Every user of digital content has a special legal position concerning digital content and special rights and obligations under a digital service contract or a contract of supply of digital content. Nevertheless, there is a question what happens with the digital content and access to digital services after user's death. In Croatian Law, the estate of inheritance "represents the totality of rights and obligations that belonged to the decedent at the time of death if they are inheritable and 
free for succession". ${ }^{1}$ What belongs to someone during his or her life is in Croatian private law explained through a definition of property by which property means anything which belonged to the decedent in the moment of death, including all subjective inheritable rights and other legal entities ${ }^{2}$. To understand what could affect someone's digital estate of inheritance it is necessary to explain what digital is. It means that this research should before stepping into inheritance law, focus on legal nature of users rights in digital world during his life.

Firstly, this article will explain the term "digital content" taking into account existing European Union legislation ${ }^{3}$ along with new directives proposals ${ }^{4}$ that aim to provide legal solutions for protection of consumer concerning digital content. So far, numerous and various digital content services have been available for users in Croatia. ${ }^{5}$ To explain legal nature of rights that users in Croatia have it is necessary

1 Gliha, I.; Josipović, T., Chapter 6: Succession Law, in: Josipović, T. (ed.), Introduction to the Law of Croatia, Alphen aan den Rijn, The Netherlands: Kluwer Law International, 2014, p. 196

2 Definition of property in inheritance law see: Matanovac, R., Nasljedivanje autorskog prava, Zbornik Pravnog fakulteta u Zagrebu, Vol. 54, No.3-4, 2004, p. 619

3 Directive 2011/83/EU of the European Parliament and of the Council of 25 October 2011 on consumer rights, amending Council Directive 93/13/EEC and Directive 1999/44/EC of the European Parliament and of the Council and repealing Council Directive 85/577/EEC and Directive 97/7/EC of the European Parliament and of the Council (hereinafter: Directive 2011/83/EU on consumer rights), OJ L 304, 22.11.2011, p. 64-88, available at: https:/eur-lex.europa.eu/legal-content/EN/TXT/?uri=celex\%3A32011L0083, last accessed: 30.01.2019. This directive is implemented in Croatian private law through Consumer protection Act, Official Journal (Official Gazette ), 41/2014, 110/2015, hereinafter: CPA). Also, of importance is Directive (EU) 2015/2366 of the European Parliament and of the Council of 25 November 2015 on payment services in the internal market, amending Directives 2002/65/EC, 2009/110/EC and 2013/36/EU and Regulation (EU) No 1093/2010, and repealing Directive 2007/64/EC (hereinafter: Directive (EU) 2015/2366 on payment services), OJ L 337, 23.12.2015, p. 35-127, available at: https://eur-lex.europa.eu/legal-content/EN/TXT/HTML/?uri=CELEX:32015L2366\&from=HR, last accessed: 30.01.2019. This directive is implemented in Croatian private law through the Act on Payment Services, Official Gazette , 66/2018, (hereinafter: APS)

4 Proposal Directive of the European Parliament and of the Council on certain aspects concerning contracts for the supply of digital content (hereinafter: Digital Content Directive Proposal), COM/2015/0634 final - 2015/0287 (COD), Brussels, 9.12.2015, available at: [https://eur-lex.europa.eu/legal-content/EN/TXT/?uri=celex\%3A52015PC0634] Accessed 02.02.2019. Another proposal that shall be taken into account is Proposal for a Directive of the European Parliament and of the Council amending Council Directive 93/13/EEC of 5 April 1993, Directive 98/6/EC of the European Parliament and of the Council, Directive 2005/29/EC of the European Parliament and of the Council and Directive 2011/83/EU of the European Parliament and of the Council as regards better enforcement and modernisation of EU consumer protection rules (hereinafter: New deal for consumers), COM/2018/0185 final - 2018/090 (COD), available at: [https://eur-lex.europa.eu/legal-content/EN/ TXT/?uri=CELEX\%3A52018PC0185] Accessed 06.02.2019

5 In Croatia 90\% of population uses Internet (December 2017) and 1, 8 million people have Facebook accounts (https://www.internetworldstats.com/europa.htm, last accessed on: 02.02.2018.). Croatian Internet users read news online $(91 \%, 2$ nd in Europe), listen to music, watch videos and play games 
to explain rules applicable to relations concerning digital content with a special research of terms and conditions of such services. Each digital service provider has its own terms or conditions of use, prepared in advance, impossible for users to change them. ${ }^{6}$ At the first sight, it might seem that users have only the right to use but it seems that users rights are not exhausted only in usage of data, that there is something more. ${ }^{7}$

That part would be a base for a discussion on digital inheritance. On the one hand, it has to be explained what is meant by digital inheritance. On the other hand, from the aspect of Croatian national inheritance law, it has to be seen what is inheritable in general and then it shall be discussed on digital inheritance.

\section{DIGITAL CONTENT}

\subsection{Defining digital content}

There are several different definitions of digital content in the European Union directives already in force or just proposed. The Directive 2011/83/EU on consumer rights briefly defines digital content as "data which are produced and supplied in digital form" ${ }^{8}$ In addition to this brief definition, the preamble to this Directive gives some examples of digital content, such as "computer programs, applications, games, music, videos or texts, irrespective of whether they are accessed through downloading or streaming, from a tangible medium or through any other means".? Some authors imply that this definition was left broad because the intention was to include all possible kinds of digital content and digital services. The idea was

online, watch films and make video calls over the Internet. This fact has been taken from: Digital Economy and Society Indeks (DESI) 2018 - Country Report Croatia, p. 6, available at: [http:// ec.europa.eu/information_society/newsroom/image/document/2018-20/hr-desi_2018-country-profile_eng_B4406AEC-AC62-A67B-2B7B633077700C13_52224.pdf] Accessed 02.02.2019

6 See more on standard contracts in the digital market: De Franceschi, A., European Contract Law and Digital Single Market: Current Issues and New Perspectives in: De Franceschi, A. (ed.): European Contract Law and Digital Single Market - The implications of the Digital Revolution, Intersentia, Cambridge, Antwerp, Portland, 2016, p. 11

7 Beside use, rights could be a right to copy, a right to distribute or analysing the data. See more: Zech, H., Data as a tradeable commodity in: De Franceschi, A. (ed.): European Contract Law and Digital Single Market - The implications of the Digital Revolution, Intersentia, Cambridge, Antwerp, Portland, 2016, p. 59

8 Art. 2 (11) of Directive 2011/83/EU on consumer rights. The same definition could be found in art. 5 (2) of the CPA

9 See more recital 19 in the preamble to Directive 2011/83/EU on consumer rights 
also to escape from standard contract typology and to avoid mentioning specific types of contracts, such as contracts on sale, rent, commission, licence or similar. ${ }^{10}$

There is another definition of digital content in the Directive (EU) 2015/2366 on payment services. According to this Directive, digital content "means goods or services which are produced and supplied in digital form, the use or consumption of which is restricted to a technical device and which do not include in any way the use or consumption of physical goods or services". Preamble to this Directive does not contain any additional examples of digital content. Here, the focus is on digital goods and services and not on data. ${ }^{11}$

Important definition of digital content is proposed in the Digital Content Directive Proposal, which aims to regulate consumers remedies in case of lack of conformity. In the first part of the definition, this proposal regulates digital content as a "data which is produced and supplied in digital form, for example video, audio, applications, digital games and any other software". ${ }^{12}$ This part of the definition of digital content is similar to the definition of digital content from the Directive 2011/83/EU on consumer rights. Nevertheless, the Digital Content Directive Proposal further continues defining digital content as "a service allowing the creation, processing or storage of data in digital form, where such data is provided by the consumer"13 and as "a service allowing sharing of and any other interaction with data in digital form provided by other users of the service". ${ }^{14}$ Preamble to Digital Content Directive Proposal emphasized that "the definition of digital content is deliberately broad and encompasses all types of digital content, including, for example, downloaded or web streamed movies, cloud storage, social media or visual modelling files for $3 \mathrm{D}$ printing, in order to be future-proof and to avoid distortions of competition and to create a level playing field". ${ }^{15}$ This definition seems to be very broad while it includes all types of digital content. The examples contained within give very important tool for clear understanding of the broad concept of digital content.

Some novelties concerning digital content are also proposed under the New deal for consumers where improved definitions of digital content, contract for the sup-

10 See more: Lehmann, M., A European Market for Digital Goods in: De Franceschi, A. (ed.): European Contract Law and Digital Single Market - The implications of the Digital Revolution, Intersentia, Cambridge, Antwerp, Portland, 2016. p. 117

$11 \quad$ Ibid., p. 112

12 Art. 2, p. 1 (a) of Digital Content Directive Proposal

13 Art. 2, p. 1 (b) of Digital Content Directive Proposal

14 Art. 2, p. 1 (c) of Digital Content Directive Proposal

15 See more under detailed explanation of the specific provisions of the proposal, Preamble to Digital Content Directive proposal 
ply of digital content, digital service and digital service contract are given. ${ }^{16}$ This means that the existing Article 2 of Directive 2011/83/EU on consumer rights should be changed. Article 2 (1) of New deal for consumer proposes the definition of the digital content as "data which are produced and supplied in digital form, including video files, audio files, applications, digital games and any other software". Furthermore, the New deal for consumers proposes to define digital service as a service "allowing the consumer the creation, processing or storage of, or access to, data in digital form or service allowing the sharing of or any other interaction with data in digital form uploaded or created by the consumer and other users of that service, including video and audio sharing and other file hosting, word processing or games offered in the cloud computing environment and social media." 17 Since both proposals aim to create a high level of consumer protection, providing different rights and remedies for them, it would be of crucial importance to have the same definitions of digital content and digital services. This approach would assure and safeguard legal certainty in consumer protection.

At this moment, in the Croatian legislation, definitions of digital content were introduced in the CPA, following the transposition of the Directive 2011/83/EU on consumer rights and in the APS, following the transposition of the Directive (EU) $2015 / 2366$ on payment services. ${ }^{18}$ The same situation is, presumably, in other EU member states, since only United Kingdom ${ }^{19}$ and Netherlands have regulated more specific rules on digital content and related contracts. ${ }^{20}$ Taking into consideration that the Directive 2011/83/EU on consumer rights is a directive of maximum harmonisation, it should be transposed in the way that the definition of digital content should not be changed or upgraded.

After comparing definitions of digital content, it is obvious that they differ from each other. This situation does not contribute to the unique application Europe wide and should be reconsidered. At the same time, the definition of the digital content should be as broad as possible. Moreover, it should be supported by an open list of examples, which would leave an open way for future digital content

$16 \quad$ See more: art. 2, p. 1, (d) of New deal for consumers

17 Article 2 (1) of New deal for consumers

18 Beside definitions of digital content, there is a definition of computer data in the Criminal Code (Official Gazette, 125/2011, 144/2012, 56/2015, 61/2015, 101/2017, 118/2018, hereinafter: CC). The Criminal Code defines computer data as any expression of facts, information or idea in a form suitable for processing in a computer system (art. 87. p. 19)

19 See more: Giliker, P., The Transposition of the Consumer Rights Directive into UK Law: Implementing a Maximum Harmonization Directive, European Review of Private Law, Issue 1, 23, 2015, pp. 5-28

20 See more: Preamble to the Digital Content Directive Proposal and the Consumer Rights Act 2015, 2015 c. 15, available at: [https://www.legislation.gov.uk/cy/ukpga/2015/15/notes] Accessed 02.02.2019 
and services and flexible jurisprudence. At the end of the day, the courts shall be competent to give the last word on the decision whether the concrete example shall be treated within the regime of the digital content or not. ${ }^{21}$ It is, nevertheless, also obvious that the spectrum of types of digital content is growing practically on a daily basis.

\subsection{Legal position of users towards digital content and digital services}

Digital content can be created by various persons: by the users of digital services, providers of those services and by the third parties. Depending on the creator of the digital content, also varies the legal position of users towards this content. Various legal acts should be consulted when assessing the rights belonging to the users in relation to the digital content and digital services, such as: $\mathrm{CPA}^{22}$, Obligations $\mathrm{Act}^{23}$, Act implementing General Data Protection Regulation ${ }^{24}$, Electronic Communications Act ${ }^{25}$, Electronic Commerce Act, ${ }^{26}$ Copyright and Related Rights $\mathrm{Act}^{27}$ and others. Nevertheless, none of those acts has any specific provisions which would expressly determine and define the object, the content and the scope of the users rights towards the digital content and digital services. In most of the cases the content and the scope of the users rights is regulated and defined through terms and conditions prepared in advance by the service provider for each digital service. ${ }^{28}$ The user is in the position to accept or to refuse the terms and conditions prepared by the service provider, without possibility of changing or amending them. Within this research, different types of service providers and different varieties of digital services and digital content have been explored. ${ }^{29}$

${ }^{21}$ For example, German court has decided that virtual money in a game is a digital content. See: LG Karlsruhe, judgement from 25.05.2016 - 18 O 7/16

22 Only CPA has special rules for digital services, which are applicable in cases where users are consumers. See more on pre-contractual information in art. $57 \mathrm{p} .1$. of CPA and right to withdrawal in art. $75 . \mathrm{p}$ 5. and art. 77. p. 9. of CPA

23 Obligations Act, Official Gazette, 35/05, 41/08, 125/11, 78/15, 29/18, hereinafter: OA

24 Act implementing General Data Protection Regulation, Official Gazette, 42/18

25 Electronic Communications Act, hereinafter: ECA, Official Gazette , 73/08, 90/11, 133/12, 80/13, $71 / 14,72 / 17$

26 Electronic Commerce Act, Official Gazette , 173/03, 67/08, 36/09, 130/11, 30/14

27 Copyright and Related Rights Act, 167/03, 79/07, 80/11, 125/11, 141/13, 127/14, 62/17, 96/18, hereinafter: CRRA

28 When it comes to other elements of legal position of a user in some cases it could be questionable whether Croatian law is applicable. Many service providers do not have their business headquarters in Croatia, they mostly have it in one of member states. This would mean that from consumer protection point of view they would have the same protection as in Croatia

29 Services that were taken into account are: Facebook and Instagram (as social media); iTunes (including iBooks store), Amazon Kindle and Deezer (books and music services); Neflix, evotv, OyoTV, Pickbox 
After analysing them, it can be concluded that those service providers are usually legal entities and traders. Users, on the other hand, are mostly natural persons under a certain age, usually consumers or even prosumers. This new name for the consumers in digital world, comes from the situations where consumers are also creators of a new digital content or data and therefore are called consumers as producers or prosumers. Digital content created and produced by the users is therefore also very often referred to as users generated content. ${ }^{30}$ According to the general terms and conditions, consumers are usually allowed to use digital content or digital service for their personal or private use only, while the public use is strictly prohibited.

The basic relation existing in the use of digital services and digital content is the one between the service provider and the user. Nevertheless, services in digital world have more than one relation. Additional relations, along with the basic one, are relations between the user and the third parties, and the relation between the provider of the service and the third parties. Third parties are, for example, holders of a copyright who have licensed their copyright to the service providers with the possibility to sublicense it to the end users. ${ }^{31}$ Usually, one contract for supply of digital content or digital service shall give a user only one right. ${ }^{32}$ Nevertheless, there are examples where, under the same contract, user has two or more different rights. ${ }^{33}$

Usually, before entering into a relationship with regard to the digital service and the digital content, each user is asked, by the general terms and conditions, to create an account with an user's name and a password. It seems that in the digital world, creating an user account technically means to "possess" data stored or accessed in relation to this account. This user account is a new way of possessing

(as video streaming services); Google Cloud and Dropbox (as cloud services); Google Gmail and Yahoo mail (as e-mail services); Steam, Origin (Electronic Arts) and Blizzard Entertainment (as gaming platform services), web hosting and domain services ([https://www.posluh.hr], [http://cro-cloud.com/ uvjeti-poslovanja/] both last accessed on 28.02.2019

30 For example such data can be created on gaming platforms and terms and condition refer to as ,user generated data". See more: Navas Navarro, S., User-Generated Online Digital Content as a Test for the EU Legislation in: Schulze, R.; Staudenmayer, D.; Lohsse, S. (ed.): Contracts for the Supply of Digital Content: Regulatory Challenges and Gaps, Hart Publishing, Nomos Verlagsgesellschaft, BadenBaden, 2017, p. 236, 242. There are different aspects on term prosumers, see more: Hatzopoulos, V.; Roma, S., Caring for sharing? The collaborative economy under EU law, Common Market Law Review, Issue 1, 54, pp. 81-127

31 An example of such services is Deezer or song stored on iTunes (author of the song is third person not service provider) or Neflix where service provider does not hold copyright or intellectual property rights on movies

32 For example a right to use an e-book for personal purposes (to read it on Kindle)

33 Creating an account on a gaming platform and "buying a game“ gives to user a licence to use a game“ but also a possibility to create new digital content - user generated content on the same platform (see: Steam, Blizzard Entertainment and Origin) 
data, so to say. In other words, username and password are means to reach the data and only the person who knows them is in the position to access data and to "possess" data. Usually, there are two categories of data. The one given to the user (such as an e-book given to the user on Kindle) and the other, data given by the user (such as any document put by the user in a cloud). Nevertheless, this does not say anything about the legal nature of user's right with respect to the said types of data, but only about the origin of the data.

Taking into consideration everything said in this chapter, the users' rights, according to their content, scope and the object, might be divided into three separate groups. Those groups might be: copyright, ownership and licence.

\section{a) copyright}

When users generate the content, they might be the holders of copyright and / or related rights regarding this content. For example, videos, photos or texts published on social media, such as Instragram and Facebook, data created as user generated data or even documents saved in a cloud that contain such data could be within this category. ${ }^{34}$ Content may be protected by copyright only if it contains copyright works, namely original intellectual creations in the literary, scientific and artistic domain, having an individual character, irrespective of the manner and form of its expression, its type, value or purpose, unless otherwise provided for in the CRRA. ${ }^{35}$ Protected works can also be so-called derivative works whichare created as alterations or adaptations of the previously existing works. ${ }^{36}$ Also, it is possible that more than one author creates one work protected as copyrighted work. ${ }^{37}$ The objects of related rights may be performances, phonograms, videograms. The users shall have related rights in those objects if the conditions for protection regulated in the CRRA are fulfilled.

Web hosting services and internet domains, are protected through other intellectual property rights. ${ }^{38}$ Under Croatian law, user shall have a right to register

34 See more: Reinemann, S.; Remmertz, F., Urheberrechte an User-generated Content, ZeitschriftfürUrheber- und Medienrecht, Heft 3, 2012, p. 217 - 227; Babovic, M., The Emperor's New Digital Clothes: The Illusion of Copyright Rights in Social Media, Cybaris ${ }^{\circledR}$ An Intellectual Property Law Review, Vol. 6 : Iss. 1, Article 6, available at: [https://open.mitchellhamline.edu/cgi/viewcontent.cgi?article=1046\&context=cybaris] Accessed 04.03.2019

35 See art. 5 p. 1 (and p. 2) of CRRA

36 Navas Navarro, S., op. cit. note 30, p. 246

37 See more: art. 11 of CRRA

38 Maeschaelck, B., Digital Inheritance in Belgium, EuCML, Heft 1, 2018, p. 39 
one domain for free, and additional only if he pays. ${ }^{39}$ Registration of an internet domain gives an user a right to exclusively use the registered domain, organize it, shape it and control its content. ${ }^{40}$

b) ownership

Users may own data i.e. data files. Ownership of data means that the user has the possibility of control of data and its possession through technical means applied in relation to the storage of and access to the data. Data are owned by the user in a special way i.e .the user is usually a possessor of the account where the data are stored or through which data may be accessed. At the same time those data may be protected by copyright or related rights, or by trade secrets or by some other right. Within this another legal framework, such rights might belong to the user or to third persons or to the service provider. This does not affect ownership of digital data within the sense of the possibility of technical control of the access and of the use of respective data. Some authors imply that the users acquire ownership of data through contract of supply of digital content, by having in mind Digital Content Directive Proposal..$^{41}$ Nevertheless, owning intangible data may in some way be similar to owning tangible things. Two elements are important here: possibility of the access and possibility of the control of data which lead to the concept of possession of data. For example, when data are in cloud or stored on a server, access is achieved through user name and password, which are known only to the user. On the other hand, control of such data can be seen through user's right to change such data or even to destroy it. ${ }^{42}$ Naturally, owning data files can be compared to the ownership of tangible goods, but may not be equalized. Nevertheless, according to the Croatian Property Act, ${ }^{43}$ the definition of ownership implies the possibility for the owner to exclude anyone else from the use of the object of his right. Ownership, under the Croatian Property Act, is an exclusive and absolute right. With relation to data, the exclusivity actually does not work in the same way since data are intangible and data ownership does not necessarily imply the possibility of the exclusion of others and absolute effect towards others. Neverthe-

39 Art. 6 of Regulation of administration and management with the top national Internet domain (hereinafter: Regulation on TLD), Official Gazette 38/2010, 81/2015, 5/2017. See more: Dragičević, D., Pravna informatika i pravo informacijskih tehnologija, Narodne novine, Zagreb, listopad 2015, p. 27

40 See art. 24 para 1 of the Regulation on TLD

${ }_{41}$ Tai Tjong Tjin, Data ownership and consumer protection, Journal of European Consumer and Market Law, Heft 4, 2018, p. 137

42 More on possible problems which might happen in case of reivindicatio see: ibid., p. $138-140$

43 Croatian Property Act, Official Gazette, 91/96, 68/98, 137/99, 22/00, 73/00, 129/00, 114/01, 79/06, 141/06, 146/08, 38/09, 153/09, 143/12, 152/14. For definition of ownership, see art. 30 
less, a kind of ownership in relation to the digital data does exist, also according to regulation of criminal offenses concerning computer data which regulate a situation when someone damages computer data that belong to others. ${ }^{44}$ Such belonging can be explained through ownership. Even more, the Act on Data Secrecy explicitly uses the terminology "data owner". ${ }^{45}$ However, the ownership of data files may be transferred. There are no obstacles for transferability of data files. The effect of the transfer of data files would be the same as in the case of the transfer of tangibles. The same legal principles ${ }^{46}$ would be applied and would not be in danger. So, it might be concluded that there is a kind of right of the user towards data, which might be called a "specific ownership" or "ownership like" right. ${ }^{47}$

For example, Bitcoin and other virtual currencies would fit within the category of ownership on the side of other users. Nevertheless, other situations would rather lead to the concept of licence, which shall be discussed infra, than to the concept of ownership. For example, the virtual goods. It is questionable whether virtual goods are actually owned by users or they have the right to use, only. The examination of the terms and conditions applied in gaming industry shows that some digital goods can be bought in a video game, such as weapons, clothes or other items needed in a game or even money that can be used in a game. For users, it might seem that they are owners of those virtual goods, but this is not true. ${ }^{48}$ In such cases, users have only licences to use those digital goods in a game although they used a button "purchase" or "buy now" which led them to a conclusion that they are owners.

\section{c) licences}

The most usual user's right arise from licences. ${ }^{49}$ Users have licences to use their accounts and to use data. Research has shown that in most of the cases, terms and conditions given by the providers are in fact licensing terms. There are two different ways of accepting and agreeing to those terms. The first would be through "click-wrap" licence, when users accept terms by clicking on a box which says "I

\footnotetext{
44 See art. 268 of Criminal Code

45 See art. 2, 14, 15 and other articles of Act on Data Secrecy, Official Gazette , 79/2007, 86/2012. This act also defines data in art. 2. Among everything else, data can be in electronical or digital form

46 Klarić, P., Vedriš, N., Gradansko pravo, Narodne novine, Zagreb, 2014, p. 10; Gavella, N., Privatno pravo, Narodne novine, Zagreb, 2019, p. 18

47 Similar is concluded in article / opinion of Hoeren, T., Big data and the Ownership in data: Recent Developments in Europe, European intellectual property review, n¹2, vol. 36, 2014, p.753

48 Kenneth, W. E., Content Creators, Virtual Goods: Who Owns Virtual Property?, Cardozo Arts \& Entertainment Law Journal, Vol. 34, num. 1, 2016., p. 261

49 In Croatian law licence contract is regulated in art. $699-724$ of OA
} 
agree" and the other is "browse-wrap", where acceptance is presumed and the terms are available on providers website. ${ }^{50}$ Generally, the provider is the one who gives licences but in cases of social media services (such as Facebook an Instagram) user is the one who gives licences to service provider to use user's photos and videos without any payment. Licences given by the provider are mostly limited, revocable, non-exclusive, personal and non-transferable, without possibility of sub-licensing.

\section{DIGITAL INHERITANCE IN CROATIA}

\subsection{Generally on Inheritability in Croatian Private Law}

In Croatian private law inheritance is regulated in the Inheritance Act (hereinafter: IA) ${ }^{51}$ Croatian inheritance law recognizes the rule of universal succession. Article 5. p. 1. of IA regulates that a person who inherits someone is his universal successor. According to the principle of ipso iure succession (art. 3. p. 1., art. 129 IA) heirs inherit decedent upon his death. Object of their inheritance is estate of inheritance. ${ }^{52}$

In general, the estate of inheritance consists of everything that belonged to decedent at the moment of his death. It might seem that all subjective property rights that belonged to decedent during his life are part of his estate of inheritance, but this is not completely true since there are rights which are not transferable mortis causa. ${ }^{53}$ Although the most of the subjective property rights are transferable it does not always mean that they are inheritable. By this reasoning, we come to the conclusion that the estate of inheritance consists of everything that belonged to descendant, if it is inheritable. This is explicitly regulated in the Art. 5 Para. 3 of the IA. Some subjective rights may not be inheritable because of their legal nature or according to the explicit provision of the law. ${ }^{54}$

The debts of the decedent burden the estate of inheritance and are inherited together with his or her economic and non-economic rights. ${ }^{55}$ Some authors classify the estate of inheritance through decedent's patrimonial rights (ownership, limited property rights, claims, leasehold interests, except for strictly personal rights), the decedent's obligations, and other decedent's legal goods and entities not hav-

\footnotetext{
50 Helberger, N; Loos, M. B. M.; Guibault, L., Mak, C., Pessers, L., Digital Content Contracts for consumers, Journal of Consumer policy, Issue 1, Volume 36, March 2013, pp. 37-57

51 Inheritance Act, Official Gazette 48/2003, 163/2003, 35/2005, 127/2013, 33/2015, 14/2019

52 See more: Gavella, Nikola, Nasljedno pravo, Narodne novine, Zagreb, 2008, pp. 55-64

53 See more on similarities and differences between property or assets and estate of inheritance in Klarić; Vedriš, op. cit., note 46, p. 716 and Gavella, ibid. p. 59, 60.

54 For example, see art. 2 p. 3 of Act on Humanitarian Aid (Official Gazette, 102/15) and decision of Croatian Constitutional Court from $12^{\text {th }}$ of June 2018, U-III/1237/2018

55 See more: Gavella, op. cit note 52, p. 62
} 
ing the character of subjective rights (possession of things, legal effect of an offer, limitation periods)" ${ }^{56}$

\subsection{Inheritability of subjective property rights in a digital world}

Digital inheritance is not regulated by specific provisions in Croatian private law. Also, there are no special provisions applicable specifically to inheritance of data, digital content or legal position of any kind for contract of supply of digital content in Croatian private law. Therefore, only the general principles of universal succession may be applied to inheritance of user's rights in digital world. As it has been already emphasized, most relations in digital world are, in a way, dualistic, since there is one set of rules for user's account and another for data that are connected to these accounts. It has to be emphasized that those relations are before everything - contractual relations. According to the Art. 213 of the OA, death of a debtor or creditor shall end the obligation only if it has been created concerning personal qualities of a contracting party or personal ability of the debtor. ${ }^{57}$ This means that the general rule for inheritability of contractual relations in case of user's death would leave an open way for his heirs to inherit decedent's legal position also with regard to the contracts related to the digital world, unless regulated otherwise. For example, the Regulation on TLD regulates that a right to use a domain name terminates upon user's death. ${ }^{58}$ Inheritability of rights in the digital world will be furtherly discussed having in mind the abovementioned differentiation between account and data provided through the account and classification of a legal base for the use (ownership, copyright and licences).

\section{a) ownership an copyright}

Some could argue that there is a difference between data stored on decedent's personal computer, USB Disk or internal hard disk and data stored online. Nevertheless, it seems that there should be no difference. The same principles should apply in both of the cases. Namely, if data are inheritable, they shall be inheritable, if data are by their nature or by the explicit provision out of the possibility to be inherited, it shall not be inheritable. It is not important how data are stored

56 Gliha; Josipović, op. cit., note 1, p. 196

57 See more: Gorenc, V.; Belanić, L.; Momčinović, H.; Perkušić, A.; Pešutić, A.; Slakoper, Z.; Vukelić, M.; Vukmir, B., Komentar zakona o obveznim odnosima, Narodne novine, Zagreb, 2014, str., 320, 321

58 See more on domains in this article: 2.2 Legal position of users towards digital content and digital services) along with art. 24 p. 3 of the Regulation on TLD. This special domains regulated under Croatian law are transferable (art. 28 of the Regulation on TLD) but uninheritable. This might not be the case if a person registers a domain in case where rules of another country apply 
or accessed. Nevertheless, technically, if heirs would like to access data that is online, under some password, they would have to prove to the provider that they are user's legitimate heirs. But the question of technical accessibility data for the heir is not relevant since the heir steps into the position of his decedent ipso iure, by the law itself, the possession or access is not relevant for the inheritance. On the other hand, if the heir would have a password, he could access data, but it does not necessarily mean that he inherited those data. Technical means are not relevant for inheritance of data. Data that could be accessed offline might also be inherited just like any other thing or right ${ }^{59}$ unless otherwise stipulated by the decedent or regulated by the law. For example, cryptocurrencies such as Bitcoin can be inherited just like the ordinary money. ${ }^{60}$ Another example are copyright in data. No matter if the data is online, in a cloud such as Dropbox, or offline, it could be protected under copyright. Croatian CRRA explicitly regulates that copyright is inheritable. ${ }^{61}$ On the other hand, inheritability of owned data - data that is not protected under the CRRA - need to be furtherly discussed.

As it was already mentioned, it is possible that within one service exist different types of users' rights. One example for such a service is Facebook. Data stored on Facebook account might be in different legal regimes with respect to the users. Videos and photos created by the user might be protected by copyright and as such inheritable, along with contractual position of user as a licensor of the licences issued to Facebook. The question remains whether the same might be applied to messages sent and received via Facebook. The answer to this question should presumably be the same as in the case of the messages sent through an e-mail or another way of electronic communication. It is clear that this content is personal and the answers to the question of inheritability of such personal communication should be assessed not only through provisions of inheritance law but also through provisions on the protection of privacy and personal data.

One might argue that e-mail and messages are actually the same as personal letters. Croatian private law does not contain any special provision on inheritability of personal letters, which means that the general principles should apply here. On the other hand, Croatian CC has a special part on criminal offenses against privacy. In the Art. 142. CC regulates that access to someone's letters, e-mails or similar without permission is considered as a criminal offence against the right

\footnotetext{
59 See: art. 79 of the IA

60 Čičin-Šain, N., Oporezivanje Bitcoina, Zbornik pravnog fakulteta Sveučilišta u Zagrebu, Vol. 67, No. 3-4, 2017, p. 657

61 See Art. 41. p. 1. CRRA. Although copyright is non-transferable right, it is inheritable (art. 42 p. 1 of the CA). On inheritability of copyright, see more: Matanovac, op. cit., note 2, pp. 607-650
} 
to privacy. ${ }^{62}$ This provision does not make any difference between ordinary mail and any other kind of electronic communication, when it comes to the breach of someone's privacy. This difference should neither exist under inheritance law. Another point of view should be seen here through the protection of privacy and protection of personal data. Privacy protection and secrecy of electronic communication are regulated in the ECA. ${ }^{63}$ However, this regulation, just like the CC, aims to protect privacy in different way and during someone's life. There are no provisions in the ECA which should be understood as providing that the messages and e-mail content should not be inheritable. Clearly, reading others messages and emails is a breach of user's privacy, but saying that they are uninheritable would be wrong. The aim of the said provision is to protect someone's privacy. However, privacy and protection of personal rights post mortem $^{64}$ should not be in the same regime, since there is no need for such a protection. This would mean that after user's death, his heirs could inherit his messages and e-emails even though they did not receive the permission of the decedent to access to this content. For heirs, this would mean that they would have to prove that they are user's heirs in order to get access from the provider. On the other hand, protection of personal datapost mortem is not the same as the protection of privacy in electronic communication inter vivos. ${ }^{65}$ Although Croatian legislator had the opportunity to regulate processing of personal data of deceased persons ${ }^{66}$ through Act on implementation of General Data Protection Regulation ${ }^{67}$ it decided not to do so and therefore the general principles should apply.

At the moment, relevant court decisions on this topic still does not exist in Croatia. That is way this part of the discussion will take into account an important decision of German Federal Court of Justice (Bundesgerichtshof, hereinafter: BGH)

62 Art. 142 of the CC

63 See articles 99a, 100 and others of ECA. Among other directives, in regulation is transposed Directive 2002/58/EC of the European Parliament and of the Council of 12 July 2002 concerning the processing of personal data and the protection of privacy in the electronic communications sector (Directive on privacy and electronic communications), Official Journal L 201, 31/07/2002 P. 0037 - 0047

64 Gavella, N., Osobna prava, Pravni fakultet Sveučilišta u Zagrebu, Zagreb 2000, pp. 33, 34

65 See more: Resta, G., Personal Data and Digital Assets after Death: a Comparative Law Perspective on the BGH Facebook Ruling, EuCML, Vol. 7, Issue 5, 2018, pp. 203, and Klas, B.; Möhrke-Sobolewski, C.: Digitaler Nachlass - Erbenschutztrotz Datenschutz, NJW 2015, p. 3476

66 Regulation (EU) 2016/679 of the European Parliament and of the Council of 27 April 2016 on the protection of natural persons with regard to the processing of personal data and on the free movement of such data, and repealing Directive 95/46/EC (hereinafter: General Data Protection Regulation) (Text with EEA relevance), OJ L 119, 4.5.2016, p. 1-88, available at: [https://eur-lex.europa.eu/legal-content/EN/TXT/?uri=celex\%3A32016R0679] Accessed 03.03.2019

67 Act implementing of General Data Protection regulation, see note 24 
from July 12 2018, III ZR 183/17 - KG ${ }^{68}$ in which existence of digital inheritance is confirmed. Plaintiffs were the parents of a minor daughter who died under strange circumstances. Respondent in this case was Facebook. Parents wanted to read their daughter's messages on Facebook in order to find out whether their daughter committed suicide or not. They had her user name and a password but her status was transformed into a memory status so they were not able to see her messages. BGH allowed the plaintiff the access to their daughter messages. The most important argument was that their daughter's contract position is transferable according to principle of universal succession. ${ }^{69} \mathrm{BGH}$ explained that the provisions of terms and conditions do not explicitly exclude inheritability and that a provision on transformation to Memorialized status upon the death is not valid as it is unfair. ${ }^{70}$ Additionally, in opinion of BGH, although messages are personal data, German Act on Electronic Communications Act ${ }^{71}$ and General Data Protection Regulation are not obstacles for inheritability of the Facebook account. ${ }^{72}$ Those arguments are of significance as a confirmation of the conclusions given in previous paragraphs because of similarities of existing legal solutions in German and Croatian law.

\section{b) licences}

Many $^{73}$ terms and conditions regulate that licences given by provider to a user are non-transferable or they have a non-transferability clause. Additionally, in some cases accounts such as Facebook, are upon the death of a user turned into a memorialized status and a user can determine during his life one person that is allowed to take care of such an account. In case of non-transferable licences situation is not as simple as in case of Facebook account where it would not have any sense for heirs to step in his decedent's legal position. There are opinions that licences which

${ }_{68}$ Decision in available thought this link: [http://juris.bundesgerichtshof.de/cgi-bin/rechtsprechung/document.py? Gericht $=$ bgh $\& A r t=e n \& s i d=763$ e 32 ddffeac 8 a $10 c 62 \mathrm{fbc} 1$ bd 813 c35 \&n $\mathrm{r}=86602 \&$ pos=0\&anz=1] Accessed 03.03.2019

69 See: $\$ 1922$ of German Civil Code (Bürgerliches Gesetzbuch), BGBl. I S. 42, 2909; 2003 I S. 738

70 BGH decision from July 12 2018, III ZR 183/17 - KG, p. 32. See also: Resta, op. cit., note 68, p. 2014.; Mackenrodt, M. - O.; Digital Inheritance in Germany, EuCML, Vol. 7, Issue 5, 2018, p. pp.44, 45; Leipold, D., Band 10: Erbrecht \$\$ 1922-2385, Münchener Kommentar zum BGB, 7. Auflage 2017, pp. $24-25$ (online version of book available on: [https://beck-online.beck.de] Accessed 09.03.2019).

${ }^{71}$ Telekommunikations gesetz, BGBl. I S. 1190. As in Croatia, in this act is implemented through the Directive on privacy and electronic communications (op. cit. in note 66)

72 See more: Etteldorf, C., About Dashcams and Digital Estate - German Federal Court of Justice Weighs $U_{p}$ Data Protection Interests, European Data Protection Law Review, Vol. 4, Issue 3, 2018, pp. 370 - 374.

73 For example, terms and conditions for Yahoo, Netfix, Dropbox, and data used under iTunes apps 
are given under the non-transferability clause might, despite this, be inheritable. Some authors argue that the judgement UsedSoft GmbH v Oracle International Corp ${ }^{74}$ in which contractual clause on non-transferability of the software licence is considered void, puts another light on the possibility of inheritance of software licences. ${ }^{75}$ Additionally, licences are in Croatian Private Law inheritable unless otherwise agreed (art. 724 p. 1. of the OA). Even if accounts are not inheritable, it should not mean that the data is also inheritable.

Although someone's contractual position is generally inheritable, a problem of inheritability lies in this contractual provisions on non-transferability of the licences. It could be agreed that such a clause is very important in cases where the service is strictly connected to a person, such as social media accounts like Facebook. On the contrary, in relations that are not connected to a person and are quite similar to rent or lease, such as iTunes, Deezer or Netflix, those clauses do not have the same purpose. In the last cases, the main aim of non-transferability clause is protection of interests of service providers. The difference between inheritance of a CD, which is a tangible thing, and a licence to access and stream or download the music online comes from the difference between legal regimes applied inter vivos. In the first case, there is inheritance of the thing which contains copyright works in relation to which the right of distribution was exhausted and therefore there is no obstacle for inheritance. In the second case, the licence is expressly non-transferrable and this could be an obstacle for inheritance. Nevertheless, it is questionable whether the non-transferability clauses should be interpreted as to be applied mortis causa if the license has not expired. Licence as such should also be inheritable, despite to the fact that it was given under the non-transferability clause. It should be remembered that a right to inherit is a right guaranteed by the Croatian Constitution. ${ }^{76}$ It is to be understood that subjective rights existing in digital world are inheritable if they are not strictly personal or not inheritable according to their nature or to the special provision. ${ }^{77}$ So, the protection of interests of service provider would not fall within any of the said categories. Additionally, in cases where users are also consumers, it could be argued that non-transferability clause is an unfair contract term. ${ }^{78}$ Consumers do not have the opportunity to ne-

74 Judgement from 3 July 2012, C-128/11, UsedSoft GmbH v Oracle International Corp, ECLI:EU:C:2012:407

75 Berlee, A., Digital Inheritance in the Netherlands, Heft 6, 2017, EuCML, p. 259

76 Art. 48 p. 4 of Constitution, Official Gazette, 56/90, 135/97, 08/98, 113/00, 124/00, 28/01, 41/01, $55 / 01,76 / 10,85 / 10,05 / 14$

77 See more on this provision in: Gavella, op. cit. note 52, p. 31

78 Art. 49 of CPA 
gotiate $^{79}$ on licence terms and from the point of inheritability, it creates imbalance between the interests of the service provider and the consumer. Such behaviour of the trader could be considered as behaviour contrary to the principle of good faith since it unnecessarily hinders inheritability of digital property.

\subsection{Possible problems with digital inheritance}

Problems concerning digital inheritance are not only connected with the clauses on non-transferability of licences. Heirs could be confronted with some other practical issues. First of all, usually heirs do not even know that their decedents had any kind of digital property. Secondly, in cases when they know that decedent used digital services which could contribute to the increase of the value of the estate of inheritance, they might not be able to access them since they do not know the access codes. Those problems could be prevented.

One of the ways for preventing the said problems could be a notarial deposit. ${ }^{80} \mathrm{Public}$ notary is obliged to take for deposit any kind of document. ${ }^{81}$ This means that a user of digital content and services can create a document with a list of his accounts along with a user name and a password. Public notary would have to make a note in a record that this deposit is made for client's heirs or someone else who could claim the document after his death. On the one hand, user might feel unsecure with this kind of revelation of his important passwords. On the other hand, since passwords should be changed from time to time, by their change, the document given to the notary would lose its purpose.

Since idea is to create legal effects mortis causa, the said problems could be resolved in the will. Both, private and public wills would be adequate to fit this purpose. However, the international wills ${ }^{82}$ would be even better especially in cases where Croatian private law might not be the applicable law. When it comes to the content of the will, testator can name a person as an executor of the will. ${ }^{83}$ The testator could entitle the will executor to transfer data to heirs or to legatee's accounts or even to close accounts.

\footnotetext{
79 See more on how licence contracts are concluded in this article under: 2.2. Legal position of users towards digital content and digital services

80 Notarial deposit is regulated in Public Notary Act in art. 109 - 113 (Official Gazette, 78/93, 29/94, $162 / 98,16 / 07,75 / 09,120 / 16)$

81 Under document is meant a regular paper but it can also be for example a Word document saved on an USB which could be an object of a deposit

82 Gavella, op. cit., note 52, pp. $141-144$

83 Gliha; Josipović, op. cit. note 1, p. 210
} 
Besides the will, users might opt for special services (for example Safe Haven ${ }^{84}$ ) that provide digital property management. This property management also covers situations of user's death, which means that the service has to follow user's orders given for the case of his death.

In a case where heirs know about the digital content owned by their decedents, in order to access them, they shall regularly need to prove to the service provider that they actually are the heirs. One way of proving this fact could be the certificate of succession. Under Croatian Law probate proceeding is ex officio conducted only in case where a real estate is a part of the property. In other cases, conduction of probate proceeding depends on the heirs or other persons with legal interest. ${ }^{85}$ Still, even if heirs have certificate of succession, it is questionable whether service provider will give the access to decedent account or not. ${ }^{86}$

The last possible problem which can be mentioned here is the determination of the value of the part of the property that is digital. It might be a problem for judges or public notaries to determine this value. There are situations where it is important to know the value of decedent's property. For example, when it comes to responsibility for debts, heir's responsibility limit is determined through the value of the estate of inheritance.

\section{CONCLUSION}

Rights in the digital world originate from the contract for the supply of digital content in order to use digital content or digital data. Although different legal sources on the EU level define digital services and digital content, a unique definition still does not exist and it should be introduced by amending active directive proposals (New deal for consumers and Digital content directive proposal). Position of a user of the digital content or digital data can be explained through two different points of view. Firstly, one set of rules regulates their position towards the account. In the most cases it is determined by the terms and conditions prepared by digital service provider. Secondly, another set of rules is relevant for the right to use digital content or data regulated through another set of rules - copyright,

${ }^{84}$ See more:[ https://safehaven.io/] Accessed 10. 03.2019

85 Art. 215 p. 2 of the IA

86 This problem has been discussed in a case of Supreme Judicial Court of Massachusetts, Ajemian v. Yahoo! (Inc. 987 NE.2d, see more: [https://www.mass.gov/files/documents/2017/10/16/12237.pdf] Accessed 10.03.2019) which opens a way for users representatives of an estate to access decedent e-mails. When it comes to inheritance and digital property in the USA see also special rules applicable in this cases: Revised Fiduciary Access to Digital Assets Act (available at: [https://www.uniformlaws.org/HigherLogic/System/DownloadDocumentFile.ashx?DocumentFileKey=112ab648-b257-97f2-48c2-61fe109a0b33\&forceDialog=0] Accessed 10.03.2019) 
ownership or licences. This is why inheritability of rights existing in the digital world depends on many factors.

Concerning the account, as it is a contractual relation, it can be concluded that it is in general inheritable according to art. 213 of the Obligations Act and the principle of universal succession (art. 5. p. 1. of the Inheritance Act). However, inheritability and the possibility to access such accounts after user's death is often confronted with obstacles. The first obstacle is non-transferability of licences for such accounts which are usually determined by terms and conditions of the service provider. Such clauses are justified in those cases where accounts are strictly personal (like social media). In other cases, for example in case of accounts created for purchase and music listening, there is no such justification for non-transferability. Courts should declare such clauses unfair and accordingly null. Additionally, it can be argued that the principle of universal succession should in some cases prevail over the non-transferability clauses.

Another obstacle is the heir's possibility to access the account. Without user name and password, accessibility depends on a discretionary decision of a service provider given after heirs request to access the account. Also, only a few service providers have special solutions for case of user's death. In most of the cases, users are not aware of non-transferability clause imposed by digital service providers. This problem could be solved, at least for the consumers, through the content of precontractual information which could be achieved by amending a proposal New deal for Consumers. Consumers should be informed on possible transferability of the account or even inheritability in advance.

When it comes to the inheritability of digital data and digital content, since there are not any special rules in the inheritance law in Croatia applicable in this case, principle of universal succession also applies. It can be concluded that e-mails, photos published on social media, messages accessible through social media accounts, data in a cloud etc., although they were private and personal to decedent, they could fall under the same regime as copyrighted work or other owned things. Also, in these situations access to the digital content and data depends on the access to the account which leads to a conclusion that the accessibility to such data is again problematic. Because of the importance of this problem, amendment to the New deal for consumer, in a part that amends Directive 2011/83/EU on consumer rights, is necessary. It should introduce special solutions for the contract of the supply of digital content in case of user's death in favour of inheritability. This is of a mayor importance especially in those cases where it is justified by nature of the accounts and data and digital content to belong to the heirs or to continue with the heirs. Without those rules, inheritability of digital data and digital con- 
tent might still depend only on behaviour of digital service providers or on court decisions after long court procedures.

\section{REFERENCES}

\section{BOOKS AND ARTICLES}

1. Berlee, A., Digital Inheritance in the Netherlands, Heft 6, 2017, EuCML, pp. 257-260

2. Čičin-Šain, N., Oporezivanje Bitcoina, Zbornik pravnog fakulteta Sveučilišta u Zagrebu, Vol. 67, No. 3-4, 2017, pp. 655-693

3. De Franceschi, A., European Contract Law and Digital Single Market: Current Issues and New Perspectives in: De Franceschi, A. (ed.): European Contract Law and Digital Single Market - The implications of the Digital Revolution, Intersentia, Cambridge, Antwerp, Portland, 2016, pp. 1 - 19

4. Dragičević, D., Pravna informatika i pravo informacijskih tehnologija, Narodne novine, listopad 2015

5. Etteldorf, C., About Dashcams and Digital Estate - German Federal Court of Justice Weighs Up Data Protection Interests, European Data Protection Law Review, Vol. 4, Issue 3, 2018, pp. $370-374$

6. Gavella, N., Osobna prava, Pravni fakultet Sveučilišta u Zagrebu, Zagreb 2000

7. Gavella, N., Privatno pravo, Narodne novine, Zagreb, 2019

8. Gavella, Nikola, Nasljedno pravo, Narodne novine, Zagreb, 2008

9. Giliker, P., The Transposition of the Consumer Rights Directive into UK Law: Implementing a Maximum Harmonization Directive, European Review of Private Law, Issue 1, 23, 2015, pp. 5-28

10. Gliha, I.; Josipović, T., Chapter 6: Succession Law, in: Josipović, T. (ed.): Introduction to the Law of Croatia, Alphen aan den Rijn, The Netherlands : Kluwer Law International, 2014, pp. $191-215$

11. Gorenc, V.; Belanić, L.; Momčinović, H.; Perkušić, A.; Pešutić, A.; Slakoper, Z.; Vukelić, M.; Vukmir, B., Komentar zakona o obveznim odnosima. Narodne novine, Zagreb, 2014

12. Hatzopoulos, V.; Roma, S., Caring for sharing? The collaborative economy under EU law, Common Market Law Review, Issue 1, 54, pp. 81-127

13. Helberger, N; Loos, M. B. M.; Guibault, L., Mak, C., Pessers, L., Digital Content Contracts for consumers, Journal of Consumer policy, Issue 1, Vol. 36, March 2013, pp. 37-57

14. Hoeren, T., Big data and the Ownership in data: Recent Development sin Europe, European intellectual property review, $\mathrm{n}^{\circ} 12$, vol. 36, 2014, pp.751-754

15. Kenneth, W. E., Content Creators, Virtual Goods: Who Owns Virtual Property?, Cardozo Arts \& Entertainment Law Journal, Vol. 34, num. 1, 2016, pp. 249-281

16. Klarić, P.; Vedriš, M, Gradansko pravo, Narodne novine, 2014

17. Klas, B.; Möhrke-Sobolewski, C.: Digitaler Nachlass - Erbenschutz trotz Datenschutz, NJW 2015, pp. 3473-3478 
18. Lehmann, M., A European Market for Digital Goods in: De Franceschi, A. (ed.): European Contract Law and Digital Single Market - The implications of the Digital Revolution, Intersentia, Cambridge, Antwerp, Portland, 2016, p. 111 - 127

19. Leipold, D., Band 10: Erbrecht SS 1922-2385, Münchener Kommentar zum BGB, 7. Auflage 2017, pp. 24 - 25 (online version of book available on: [https://beck-online.beck.de] Accessed 09.03.2019)

20. Mackenrodt, M. - O., Digital Inheritance in Germany, EuCML, Vol. 7, Issue 5, 2018, p. pp. $41-47$

21. Maeschaelck, B., Digital Inheritance in Belgium, EuCML, Heft 1, 2018, p. 37-41

22. Matanovac, R., Nasljedivanje autorskog prava, Zbornik Pravnog fakulteta u Zagrebu, Vol. 54, No. 3-4, 2004, pp. 607-650

23. Navas Navarro, S., User-Generated Online Digital Content as a Test for the EU Legislation in: Schulze, R.; Staudenmayer, D.; Lohsse, S. (ed.): Contracts for the Supply of Digital Content: Regulatory Challenges and Gaps, Hart Publishing, Nomos Verlagsgesellschaft, BadenBaden, 2017

24. Reinemann, S.; Remmertz, F., Urheberrechte an User-generated Content, Zeitschrift für Urheber- und Medienrecht, Heft 3, 2012, p. 217 - 227

25. Resta, G., Personal Data and Digital Assets after Death: a Comparative Law Persppective on the BGH Facebook Ruling, EuCML, Vol. 7, Issue 5, 2018, pp. 203. 201-204

26. Tai Tjong Tjin, Data ownership and consumer protection, Journal of European Consumer and Market Law, Heft 4, 2018, p. 136 - 140

27. Zech, H., Data as a tradeable commodity in: De Franceschi, A. (ed.): European Contract Law and Digital Single Market - The implications of the Digital Revolution, Intersentia, Cambridge, Antwerp, Portland, 2016, p. 51 - 81

\section{EU LAW}

1. Directive 2002/58/EC of the European Parliament and of the Council of 12 July 2002 concerning the processing of personal data and the protection of privacy in the electronic communications sector (Directive on privacy and electronic communications), Official Journal L 201, 31/07/2002

2. Directive 2011/83/EU of the European Parliament and of the Council of 25 October 2011 on consumer rights, amending Council Directive 93/13/EEC and Directive 1999/44/EC of the European Parliament and of the Council and repealing Council Directive 85/577/ EEC and Directive 97/7/EC of the European Parliament and of the Council, OJ L 304, 22.11.2011

3. Directive (EU) 2015/2366 of the European Parliament and of the Council of 25 November 2015 on payment services in the internal market, amending Directives 2002/65/EC, 2009/110/EC and 2013/36/EU and Regulation (EU) No 1093/2010, and repealing Directive 2007/64/EC, OJ L 337, 23.12.2015

4. Proposal Directive of the European Parliament and of the Council on certain aspects concerning contracts for the supply of digital content (hereinafter: Digital Content Directive Proposal), COM/2015/0634 final - 2015/0287 (COD), Brussels, 9.12.2015 
5. Proposal for a Directive of the European Parliament and of the Council amending Council Directive 93/13/EEC of 5 April 1993, Directive 98/6/EC of the European Parliament and of the Council, Directive 2005/29/EC of the European Parliament and of the Council and Directive 2011/83/EU of the European Parliament and of the Council as regards better enforcement and modernisation of EU consumer protection rules (hereinafter: New deal for consumers), COM/2018/0185 final - 2018/090 (COD)

6. Regulation (EU) 2016/679 of the European Parliament and of the Council of 27 April 2016 on the protection of natural persons with regard to the processing of personal data and on the free movement of such data, and repealing Directive 95/46/EC (Text with EEA relevance), OJ L 119, 4.5.2016

\section{COURT OF JUSTICE OF THE EUROPEAN UNION}

1. Judgement from 3 July 2012, C-128/11, UsedSoft GmbH v Oracle International Corp, ECLI:EU:C:2012:407

\section{LIST OF NATIONAL REGULATIONS, ACTS AND COURT DECISIONS}

\section{a) Croatia}

1. Act implementing General Data Protection Regulation, Official Gazette, 42/18

2. Act on Electronic Communications, Official Gazette, 73/08, 90/11, 133/12, 80/13, 71/14, $72 / 17$

3. Act on Humanitarian Aid, Official Gazette, 102/15

4. Act on Payment Services, Official Gazette, 66/2018

5. Constitution, Official Gazette, 56/90, 135/97, 08/98, 113/00, 124/00, 28/01, 41/01, $55 / 01,76 / 10,85 / 10,05 / 14$

6. Consumer protection Act, Official Gazette, 41/2014, 110/2015

7. Copyright and Related Rights ActOfficial Gazette , 167/03, 79/07, 80/11, 125/11, 141/13, 127/14, 62/17, 96/18

8. Criminal Code Official Gazette, 125/2011, 144/2012, 56/2015, 61/2015, 101/2017, $118 / 2018$

9. Croatian Property Act, Official Gazette, 91/96, 68/98, 137/99, 22/00, 73/00, 129/00, $114 / 01,79 / 06,141 / 06,146 / 08,38 / 09,153 / 09,143 / 12,152 / 14$

10. Decision of Croatian Constitutional Court from 12th of June 2018, U-III/1237/2018

11. Electronic Commerce Act, Official Gazette, 173/03, 67/08, 36/09, 130/11, 30/14

12. Inheritance Act, Official Gazette 48/2003, 163/2003, 35/2005, 127/2013, 33/2015, $14 / 2019$

13. Obligations Act, Official Gazette, 35/05, 41/08, 125/11, 78/15, 29/18

14. Public Notary Act, Official Gazette, 78/93, 29/94, 162/98, 16/07, 75/09, 120/16

15. Regulation of administration and management with the top national Internet domain, Official Gazette, 38/2010, 81/2015, 5/2017 


\section{b) Germany}

1. Telekommunikationsgesetz, BGBI. I S. 1190

2. German Civil Code (Bürgerliches Gesetzbuch), BGBl. I S. 42, 2909; 2003 I S. 738

3. LG Karlsruhe, judgement from 25.05.2016. - 18 O 7/16

4. BGH judgerment from 12. 07. 2018, III ZR 183/17 - KG

\section{c) USA}

1. Judgement of Supreme Judicial Court of Massachusetts, Ajemian v. Yahoo!, Inc. 987 N.E.2d

2. Revised Fiduciary Access to Digital Assets Act

\section{WEBSITE REFERENCES}

1. Babovic, M., The Emperor's New Digital Clothes: The Illusion of Copyright Rights in Social Media, Cybaris ${ }^{\circ}$ An Intellectual Property Law Review, Vol. 6, Iss. 1, Article 6, available at: [https://open.mitchellhamline.edu/cgi/viewcontent.cgi?article=1046\&context=cybaris] Accessed 09.03.2019

2. Digital Economy and Society Indeks (DESI) 2018 - Country Report Croatia, p. 6, available at: [http://ec.europa.eu/information_society/newsroom/image/document/2018-20/hrdesi_2018-country-profile_eng_B4406AEC-AC62-A67B-2B7B633077700C13_52224. pdf] Accessed 09.03.2019

3. [https://www.internetworldstats.com/europa.htm] Accessed 09.03.2019 